\title{
Assessment of the Impact of Fadama III Development Project on Beneficiaries in Nasarawa State, Nigeria
}

\author{
${ }^{* 1} \mathrm{KUZA}$ Y., ${ }^{2} \mathrm{OKWOCHE} \mathrm{V.} \mathrm{A.} \mathrm{and}{ }^{2}$ AGE A. I.
}

\begin{abstract}
${ }^{1}$ Department of Agricultural Education, College of Education Akwanga, Nasarawa State. ${ }^{2}$ Department of Agricultural Extension and Communication, University of Agriculture, Makurdi, Benue State.
\end{abstract}

\section{ARTICLE INFO}

Article No.: 091018133

Type: Research

DOI: 10.15580/GJAS.2018.9.091018133

Submitted: 10/09/2018

Accepted: 11/09/2018

Published: 25/09/2018

${ }^{*}$ Corresponding Author

KUZA Y.

E-mail: ykuza2018@gmail.com

Keywords:

Assessment, Impact, Fadama III

project, Nasarawa
This research was carried out to assess the impact of Fadama III project on beneficiaries in Nasarawa State, Nigeria. Two hundred and twenty respondents, who were beneficiaries were selected for the study using Multi-stage, stratified and simple random sampling techniques. Primary data were collected using a structured questionnaire. Research findings revealed that most of the respondents were aged between 31 and 35 years $(28.6 \%)$, predominantly male (63.2\%), had a household size of $4-6$ persons $(40.9 \%)$, possessed formal education (81.4\%), had farms below $3 \mathrm{Ha}(45.0 \%)$ and had farming experience below 10 years (59.3\%). Participation in Fadama III project had significant impact on the farm income (sig. $=0.000$ ) and output (sig. $=0.000$ ) of the respondents. The constraints encountered by the respondents were administrative and economic in nature. It was recommended that more farmers be encouraged to participate in the project, and financial support provided to the beneficiaries. Also, administrative challenges to the operation of the project should be sorted out by the government and donor agencies. 


\section{INTRODUCTION}

Agriculture plays an important role in Nigerian economic development through the provision of food, raw materials for agro-allied industries, employment generation, foreign exchange and source of income (Ani, 2014). The Federal Government of Nigeria attempted to reduce poverty and facilitate rural and agricultural development, therefore, introduced several rural and agricultural development programmes and projects decades ago till date. One of the programmes introduced was the National Fadama project, which is in phases. The latest phase is the Fadama III project.

National Fadama Development Project (NFDP) is a rural and agricultural development project in Nigeria, the idea was conceived by the World Bank, African Development Bank and the Federal Government of Nigeria with active participation of the States and Local Governments (Sobanke, 2008). The National Fadama development project is a sustainable rural and agricultural development project with a wide spectrum targeted at dry season farming, related agro-processing and marketing activities. This is to meet the food demand of the fast growing population of Nigerians, enhance land and water resources management (Nasiru, Tijani and Azeez, 2006).

Fadama refers to low lying land that is subject to seasonal flooding or water logging along the river banks, streams or depressions. It is a Hausa word meaning; the seasonally flooded or floodable plains along major savannah rivers with depressions adjacent to seasonally or perennially flowing streams and rivers. With favourable agro-environment and ecological conditions, Nigeria is endowed with underground and surface water reservoirs and low-lying plains with alluvial deposits called Fadama (Agbamu, 2008).

The National Fadama III Development Project (NFDP III) is a follow up project on the success of the National Fadama II Development Project. The National Fadama III Development Project was implemented in all the 36 states of the Federation including the Federal Capital Territory (F.C.T) Abuja (Chima and Nwachukwu, 2007). It is funded by the International Development Agency (IDA). The broad objective of NFDP III is poverty reduction through increase in the income of the beneficiaries on sustainable basis. The specific objectives of the project were to reduce rural poverty, ensure food security and contribute to the achievement of the key Millennium Development Goal of food security (Oriola, 2009). NFDP III relies on the facilitation of demand-driven investments and the empowerment of local community groups to improve farm and non-farm productivity and land quality. The project has been running in Nasarawa State, and it will be necessary to ascertain if it has had positive impacts on the beneficiaries in the state. This forms the main objective of this study. The specific objectives were to:
1. describe the socio-economic characteristics of beneficiaries of the National Fadama III Development Project in the study area;

2. determine the impact of NFDP III intervention on beneficiaries in the study area; and

3. identify the constraints encountered by beneficiaries of the NFDP III intervention in the study area.

The following hypothesis was stated and tested:

The NFDP III intervention had no impact on the productivity of beneficiaries of NFDP III in the study area.

\section{MATERIALS AND METHODS}

\section{The Study Area}

This study was conducted in Nasarawa State. The State was created on 1st October, 1996 with headquarters at Lafia. It is located between latitudes $7^{\circ}$ and $9^{\circ}$ North and longitudes $7^{0}$ and $10^{\circ}$ East. It shares boundaries with Benue State to the south, Kogi State to the West the Federal Capital Territory (FCT), Abuja to the north West, Kaduna and Plateau States to the north-east and Taraba State to the south-east. Nasarawa State falls within the north-central geo-political zone of Nigeria. It has a land area of $12,000 \mathrm{~km}^{2}$ and consists of 13 Local Government Areas namely: Akwanga, Awe, Doma, Karu, Keana, Keffi, Kokona, Lafia, Nasarawa, Nassarawa-Eggon, Obi, Toto and Wamba (Nasarawa State Government, 2008).

The State has a population a projected population of 2,163,275 people (NPC, 2015). The state has 23 major ethnic groups, namely Afo, Agatu, Bassa, Egbura, Eggon, Fulani, Gade, Gbagyi, Gwandara, Hausa, Jukun, Kantana, Kanuri, Koro, Mada, Nyankpa, Rindre, Tiv, Igbo and Yoruba, among others. Agriculture is the most predominant occupation in the state. Major agricultural crops produced in the state include maize, sorghum, millet, rice, groundnut, cowpea, soya beans, cassava, melon, yam, sweet potatoes, sugarcane and tree crops. Livestock animals produced include cattle, sheep, goats and pigs. Other domestic animals produced include chickens, ducks, and fishes (Nasarawa State Government, 2008).

\section{Method of Data Collection}

Data for this study were collected from primary sources. Primary data were collected through the use of a structured questionnaire alongside interview schedule. The questionnaire consisted of three sections; $A, B$ and C. Section A dealt with socio-economic characteristics of the respondents. Section $B$ dealt with the impact of NFDP III on rural livelihood of the respondents, while section $\mathrm{c}$ focused on the constraints encountered during 
implementation of NFDP III intervention by the respondents.

\section{Population and Sample size selection}

The population of the study consisted of all the beneficiaries of the National Fadama III Development Project in Nasarawa State. Multi-stage, stratified and simple random sampling techniques were used to select the respondents for the study. In the first stage, all the three agricultural development project zones across the state were involved, namely; central, southern and western zones. Two Local Government Areas (LGAs) were randomly selected to obtain a total of six LGAs. The selected Local Government Areas were Akwanga and Nasarawa Eggon LGAs in the Central Zone, Kokona and Keffi LGAs in the Western Zone and Lafia and Doma LGAs in the Southern Zone.

In the second stage, five (5) Fadama Community Associations (FCAs) were randomly selected from each of the six (6) Local Government Areas based on their active participation in the National Fadama III project activities, making a total of thirty $(5 \times 6=30)$ FCAs. The number of participants in the selected FCAs was 1098. In the third stage, $20 \%$ of the members from each selected Fadama user groups (FUGs) were randomly selected across the three Zones bringing to a total sample size of 220 respondents.

\section{Data Analysis Techniques}

The data for this study were analyzed by using both descriptive and inferential statistics. Descriptive statistics such as frequencies, percentages and mean were used to achieve objective 1 . Student t- test was used to achieve objective 2, while factor analysis was used to achieve objective 3 . Student t- test was also used to test hypothesis.

\section{RESULT AND DISCUSSION}

\section{Socio-economic Characteristics of Respondents}

The result as presented in Table 1 showed that about 29 $\%$ of the respondents were within the age range of 31-35 years, while $11.4 \%$ were within the range of $18-24$ years. This implies that majority of the respondents were within the active and productive age range, and can contribute to the needed farm labour. This results confirmed the findings of Sobanke (2008), who reported that most Nigerian farmers were within the age range of 25 and 40 years.

The result in Table 1 also indicated that majority $(63.0 \%)$ of the respondents were male. This means the male respondents dominated Fadama III activities in the study area. His could be because the males are stronger than the females, and have more access to agricultural resources for production. This result confirmed the findings of Chima and Nwachukwu (2007) who found that male farmers tend to dominated Fadama III activities.

Research findings reveal that about $71 \%$ of the respondents were married. This means that majority $(71$ $\%)$ of the respondents were married. This implies that family labor could be largely depended upon to provide sustainable labour work force for agricultural and rural development activities in the study area. Availability of family labour is further confirmed, as majority of the respondents $(41.0 \%)$ had a household size ranging between 4 and 6 persons.

With respect to the level of education of the respondents, it was found that $81.4 \%$ of the respondents had one level of formal education or the other. The respondents are therefore literate, and can understand the intricacies required for Fadama farming. Furthermore, research findings reveal that $45 \%$ of the respondents had farm size below 3 hectares. This implies that majority of the respondents had small farm sizes, and are small scale farmers. They therefore need to make optimum use of their small farm lands, and Fadama farming could help in achieving that. The result is in agreement with that of Ani (2014), who discovered that Fadama III in Abuja is dominated by small-scale farmers who have fragmented farms.

Result on the farming experience of the respondents revealed that about $60 \%$ of the respondents had years of farming experience between 1 and 10 years, while about $11 \%$ had farming experience above 30 years. This implies that the respondents have not been engaged in farming for long, and the introduction of Fadama farming could have stimulated the interest of the respondents into farming. 
Table 1: Socio-economic Characteristics of Respondents $(\mathbf{n}=\mathbf{2 2 0})$

\begin{tabular}{|c|c|c|}
\hline Socioeconomic Characteristics & Frequency & Percentage \\
\hline \multicolumn{3}{|l|}{ Age (Years) } \\
\hline$\leq 24$ & 25 & 11.4 \\
\hline $25-30$ & 43 & 19.5 \\
\hline $31-35$ & 63 & 28.6 \\
\hline $36-40$ & 49 & 22.3 \\
\hline$>40$ & 40 & 18.2 \\
\hline \multicolumn{3}{|l|}{ Sex } \\
\hline Male & 139 & 63.2 \\
\hline Female & 81 & 36.8 \\
\hline \multicolumn{3}{|l|}{ Marital Status } \\
\hline Single & 49 & 22.3 \\
\hline Married & 171 & 77.7 \\
\hline \multicolumn{3}{|l|}{ Household size (Persons) } \\
\hline$\leq 3$ & 16 & 7.3 \\
\hline $4-6$ & 90 & 40.9 \\
\hline $7-9$ & 79 & 35.9 \\
\hline$\geq 10$ & 35 & 15.9 \\
\hline \multicolumn{3}{|l|}{ Level of Education } \\
\hline Formal education & 179 & 81.4 \\
\hline Non-formal education & 41 & 18.6 \\
\hline $\begin{array}{l}\text { rarm size (Ha) } \\
\leq 3\end{array}$ & 99 & 45.0 \\
\hline $3.1-7.0$ & 77 & 35.0 \\
\hline $7.1-10.0$ & 25 & 11.4 \\
\hline $\begin{array}{l}>10 \\
\text { Farming experience (Years) }\end{array}$ & 19 & 8.6 \\
\hline$\leq 10$ & 126 & 59.3 \\
\hline $11-20$ & 40 & 18.2 \\
\hline $21-30$ & 31 & 14.1 \\
\hline$>30$ & 23 & 10.5 \\
\hline
\end{tabular}

\section{Impact of Fadama III on Beneficiaries}

The impact of Fadama III on beneficiaries was ascertained by comparing their income and yield before, and after they became beneficiaries. The result obtained is presented in Table 2. Research findings revealed that there is a mean difference of $\mathrm{N} 224,386.1$ in the income of beneficiaries after becoming members of NFDP III. The difference in the income was significant at $1 \%$ level of probability (Sig. $=0.000$ ). This is an indication that the NFDP III project has significantly increased the income of respondents. This could be because they would engage in dry season farming, which would increase their output and income.
There was also a mean difference of $8.014 \mathrm{Kg}$ in the yield of beneficiaries after becoming members of NFDP III. The difference in the yields is significant at $1 \%$ level of probability $($ Sig. $=0.000)$. The NFDP III project has therefore significantly increased the farm yield of beneficiaries. This is because they would produce more using irrigation during off farm seasons. The null hypothesis which states that NFDP III has no significant effect on the productivity of the beneficiaries is therefore rejected. Ani (2014) also found Fadama III to significantly increase the income of participants in FCT, Abuja. 
Table 2: Impact of Fadama III Project on the Income and Yield of Beneficiaries

\begin{tabular}{llllll}
\hline Variables & Mean & $\begin{array}{l}\text { Std. } \\
\text { Deviation }\end{array}$ & $\begin{array}{l}\text { Mean } \\
\text { Difference }\end{array}$ & T & Sig. \\
\hline $\begin{array}{l}\text { Annual farm income } \\
\text { before NFDP III (N) } \\
\begin{array}{l}\text { Annual farm income } \\
\text { after NFDP III (N) }\end{array}\end{array}$ & $788,636.36$ & $4,888,270.83$ & 224386.4 & 13.656 & $0.000^{*}$ \\
$\begin{array}{l}\text { Annual farm yield } \\
\text { before NFDP III } \\
\text { (Kg/bags) }\end{array}$ & 43.81 & 34.354 & 8.014 & 4.636 & $0.000^{*}$ \\
$\begin{array}{l}\text { Annual farm yield } \\
\text { after NFDP III } \\
\text { (Kg/bags) }\end{array}$ & 51.83 & 29.369 & & & \\
\hline
\end{tabular}

\section{Constraints Encountered by Beneficiaries of NFDP III}

The factor analysis result in Table 3 showed that there were two categories of constraints affecting beneficiaries of the NFDP III intervention in the study area. The constraints were administrative and economic related. The socio-economic factor that affects beneficiaries in the implementation of the NFDP III in the area were delayed disbursement fund (0.855), delay in counterpart funding (0.819), high rate of corruption (0.842), poor implementation (0.854), weak monitory and supervision (0.499) and delay in supply of inputs (0.827).

The economic challenges faced by the beneficiaries were price inflation (0.695), high cost of transport (0.692), high cost of labour (0.637) and poor packaging method (0.842). Addressing these challenges would therefore go a long way in encouraging the farmers to increase their productivity.

\begin{tabular}{lcc}
\multicolumn{3}{c}{ Table 3: Constraints Encountered by NFDP III Beneficiaries } \\
\hline Variables & Factor 1 & Factor 2 \\
\hline Delayed Disbursement Fund & $0.855^{*}$ & 0.015 \\
Delay in Counterpart Funding & $0.819^{\star}$ & 0.192 \\
Attending Meetings lately & $0.217^{*}$ & 0.218 \\
High Rate of Corruption & $0.842^{*}$ & 0.285 \\
Poor Implementation & $0.854^{*}$ & 0.192 \\
Weak Monitory And Supervision & $0.499^{*}$ & 0.291 \\
Delay In Supply of Inputs & $0.827^{*}$ & 0.012 \\
Security Challenges & 0.196 & 0.198 \\
Price Inflation & 0.187 & $0.695^{*}$ \\
High Cost of Transport & 0.054 & $0.692^{*}$ \\
Land Tenure & 0.278 & 0.016 \\
High Cost of Labour & 0.193 & $0.637^{*}$ \\
Delay In Tractor-Hiring Service & 0.028 & 0.128 \\
Poor Packaging Method & 0.281 & $0.842^{\star}$ \\
Poor Storage Skills & 0.289 & 0.295 \\
Weak agric. Extension Services & 0.183 & 0.175 \\
\hline
\end{tabular}

\section{CONCLUSION AND RECOMMENDATIONS}

The findings of this study revealed a population that is predominantly youthful, with large household size, mostly literate, possessing small farms and low farming experience. Indulging in Fadama III project has significantly increased the farming income and yield of the respondents. The constraints to the operation of Fadama III project were administrative and economic in nature. Based on these findings, the following recommendations were made:
1. More farmers should be encouraged by agricultural extension agents to participate in the Fadama III project, as this would increase their income and productivity.

2. Financial support could be granted to the farmers for participating in the Fadama III project, as one of their challenges is economical.

3. The administrative challenges in the operation of the Fadama III project should be looked into by the government and donor agencies, as this will facilitate the smooth operation of the project. 


\section{REFERENCES}

Agbamu, J.U. (2008), Prospective in Agricultural extension and rural development. $1^{\text {st }}$ edition. Owerri, Spring Field Publishers Itd. Pp 340-345.

Agwu, A. E. (2004). Factors influencing adoption of improved Agricultural production technologies in Nigeria. Journal of International Agricultural and Extension, (11): 81-88.

Ani, I.I (2014). Impact of National Fadama II Development Project on Agricultural Productivity in Federal Capital Territory, Abuja. Unpublished postfield seminar M.Sc.Thesis presented to the Department of Agricultural Extension and Communication University of Agriculture, Makurdi. p67.

Chima, I. E and Nwachukwu, I.N. (2007). Impact of selected rural development programme on poverty alleviation in Ikwuano LGA, Abia State, Nigeria. Africa Journal of Food, Agriculture, Nutritional and Development, Kenya, 7(5):1-17.

Nasarawa State Government, (2008). Nasarawa State geographical information Services media. Lafia. pp10-15.

Nasiru, A., Tijani, A.O and Azeez, A.I (2006). Factor Influencing the Adoption of Innovation of Farm Production Practices among Small and Medium Scale Farmers in Nigeria. Australian Journal of Business and Management Research,2(2):15-25.

Oriola, E.O. (2009). A Frame Work for Food Security and Poverty Reduction Nigeria. European Journal of Social Science, (1):14-17.

Sobanke, S. B. (2008). Impact of National Development Project II on Small Scale Farmers in Ogun State. Implication for Agricultural Financing in Nigeria Journal of Sustainable Development in Africa Pennsy Ivania, 10 (3):25-38. 